
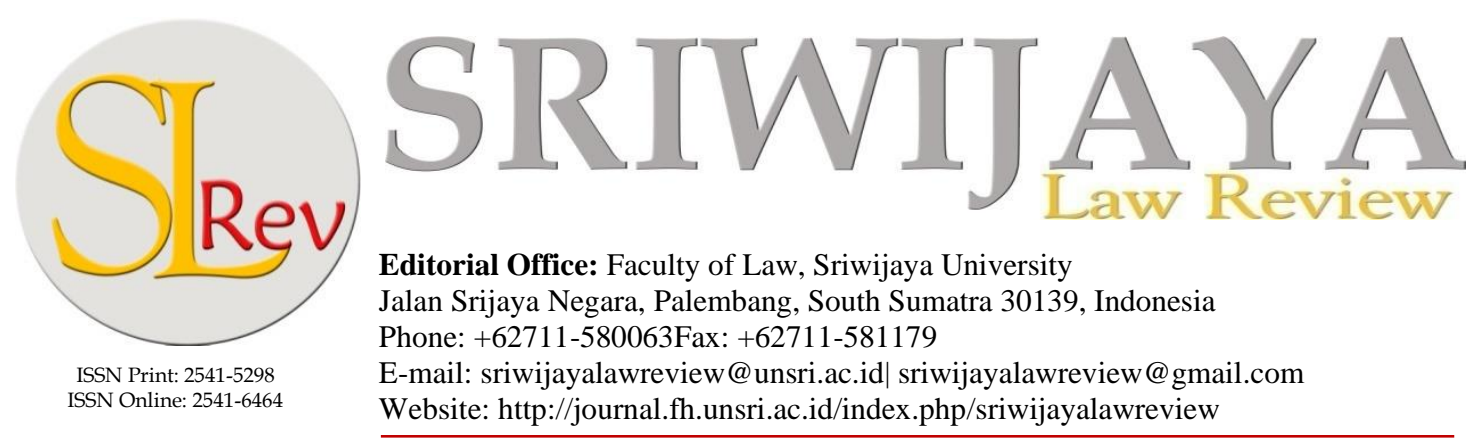

Editorial Office: Faculty of Law, Sriwijaya University

Jalan Srijaya Negara, Palembang, South Sumatra 30139, Indonesia

Phone: +62711-580063Fax: +62711-581179

E-mail: sriwijayalawreview@unsri.ac.id|sriwijayalawreview@gmail.com

Website: http://journal.fh.unsri.ac.id/index.php/sriwijayalawreview

\title{
The Legal Implication of Political Defection on Nigeria's Democracy
}

\author{
Khalid Idris Nuhu ${ }^{a^{*}}$ \\ $a^{*}$ Corresponding Author. \\ Faculty of Law, Yobe State University, Damaturu, Nigeria. E-mail: $\underline{\text { Kha- }}$ \\ lididrees03@gmail.com
}

\begin{tabular}{|c|c|}
\hline Article & Abstract \\
\hline $\begin{array}{l}\text { Article History } \\
\text { Received: Feb 7, 2021; } \\
\text { Reviewed: Jun 26, 2021; } \\
\text { Accepted: Jul 14, 2021; } \\
\text { Published: Jul 31, } 2021 .\end{array}$ & $\begin{array}{l}\text { The prevalence of cross-carpeting in Nigerian politics continues to threaten the } \\
\text { consolidation of democracy in the country. It is strengthened by the prolifera- } \\
\text { tion of political parties devoid of entrenched ideology or political philosophy } \\
\text { besides attaining political and economic powers. The unusually delayed justice } \\
\text { in defection related matters sometimes occasioned by the pile of cases before } \\
\text { the scanty judicial umpire in the country is another block of stumbling over. } \\
\text { The technical approach of these umpires to cases of defection or constitutional } \\
\text { matters may not be far from being a cloak on the wheel of justice. While the } \\
\text { elected executives at the detriment of their electorates enjoyed the freedom of } \\
\text { assembly and association in changing their political parties after the election, } \\
\text { the exercise of the same right by the elected members of legislative houses are } \\
\text { subjected to certain occurrences in justification or else vacate their seats on the } \\
\text { pronouncement of their respective leaders in the house. This historical political } \\
\text { menace persistently thrives in the country's fledgling democracy without ade- } \\
\text { quate legal instruments for effective redress. Through the conceptual approach, } \\
\text { the study reveals that the elected executives persistently swindle the mandate of } \\
\text { their voters with impunity while the principal officers of the parliaments freely } \\
\text { decide who remains or exits the house on the ground of defection. It is clear that } \\
\text { the Nigerian Anti Defection Law is inadequate in the changing political land- } \\
\text { scape of the country. This paper recommends a law reform to affect some en- } \\
\text { actments, particularly in the Constitution whereby machinery for the vacation } \\
\text { of a seat in the parliament after defection can be beyond the powers of the prin- } \\
\text { cipal officers, which is necessary for the attainment of socio-political orders in } \\
\text { the country. }\end{array}$ \\
\hline & \\
\hline
\end{tabular}

\section{INTRODUCTION}

The political morality of Nigerian politics has, over the years, come under series of challenges on account of the activities of some political gladiators in the Nigerian political arena. The challenges incessantly ravaging the scene of politics in the country include but are not limited to the joyful switch of the political platform under which a candidate for election was returned successfully at the detriment of the electorates. The prevalence of this political twist in Nigerian politics seemingly 
with impunity is spontaneously becoming legendary. It is pathetic to note that the practice is systematically orchestrated at a time when the traumatized electorates have little or nothing to offer in an altercation of their revered candidate 'crossing the carpet'.

The seed of defection in Nigeria was launched in $1951^{1}$ in the then Western House of Assembly turned the chamber into an arena for personality rivalries. The personality clash between Chief Ladoke Akintola and his former boss Chief Obafemi Awolowo that lingered for a reasonably long time, which resulted in the brutal violence that led to the first coup ${ }^{2}$ in Nigeria may not be unconnected with the stormbound political development in the parliament. Similarly, the overturn between Nnamdi Azikiwe of the National Council of Nigeria and Cameroons (NCNC) and Kingsley Mbadiwe led to the birth of another party, the Democratic Party of Nigeria Citizens (DPNC) ${ }^{3}$ under the leadership of Mbadiwe was another cause for a strained relationship between the two nationals.

The defection of Chief Akin Omoboriowo, the Deputy Governor ${ }^{4}$ of Ondo State under the Unity Party of Nigeria (UPN) to become the Ondo State gubernatorial candidate of NPN in $1983^{5}$ was seen to have been part of the remote causes of the then post-election crisis in Ondo State. ${ }^{6}$ In the same vein, many political gladiators defected to form and register new political parties on the slightest incongruity possible. A recount of the incidents that recorded Alhaji Abubakar Rimi, who defected from his Peoples' Redemption Party (PRP) and sought re-election under the Nigeria People's Party (NPP) ${ }^{7}$ and that of Alhaji Waziri Ibrahim, who founded the Great Nigeria Peoples Party (GNPP) to abandon his original party, the $\mathrm{NPP}^{8}$ on a disagreement over the "post of the Party Chairman and Presidential candidate' ${ }^{9}$ between them can be brought to the fore.

The gale of defection in the Nigerian polity became renewed after the return of Nigeria to democracy in 1999 on the celebrated defection of the then Vice President of the Federal Republic of Nigeria Alhaji Atiku Abubakar of the People's Democratic Party (PDP) to the Action Congress and became its presidential flag bearer. ${ }^{10}$ There has never been a time Nigeria went into elections without recording cases of defection to the perceived winning party. It is manifestly the result of politicking devoid of political ideology. Thus, the impression about Nigerian politics is that moving

Olu Awofeso and Paul A. Irabor, "Party Cross-Carpeting in Nigeria's Fourth Republic: Cases and Causes," Journal of Public Administration and Governance 6, no. 9 (2016): 34.

2 Awofeso and Irabor.

3 Enobong Mbang Akpambang and Omolade Adeyemi Oniyinde, "Political Party Defections by Elected Officers in Nigeria: Nuisance or Catalyst for Democratic Reforms?," International Journal of Research in Humanities and Social Studies 7, no. 2 (2020): 12.

4 Awofeso and Irabor, "Party Cross-Carpeting in Nigeria's Fourth Republic: Cases and Causes."

5 Akpambang and Oniyinde, "Political Party Defections by Elected Officers in Nigeria: Nuisance or Catalyst for Democratic Reforms?"

6 A. Adewale, "The History and Law of Political Carpet Crossing in Nigeria," Squib Guest, 2009, www.squibguest.blogspot.com.

7 Akpambang and Oniyinde, "Political Party Defections by Elected Officers in Nigeria: Nuisance or Catalyst for Democratic Reforms?"

8 "The Great Nigeria Peoples Party (GNPP)," Class Hall, 2021.

9 "The Great Nigeria Peoples Party (GNPP)."

10 VOA, "Nigeria's Opposition Party Chooses Vice President Atiku Abubakar as Presidential Candidate," voanews.com, 2009, https://www.voanews.com/archive/nigerias-opposition-party-chooses-vice-president-atikuabubakar-presidential-candidate. 
from one political party to another is common and seen to gain an advantage over other political parties. $^{11}$

While in other climes where politics of ideology reigns, politicians defect only based on the change in their believes and remain in the new platform for as long as their beliefs in the new ideologies existed. Unlike the case with Nigerian politicians, Winston Churchill ${ }^{12}$ of the Liberal Democrats defected to the Conservative Party and never changed his party again till his death. ${ }^{13}$ Similarly, Ronald Reagan ${ }^{14}$ of the Democratic Party defected to and died with the belief of the Republican Party. ${ }^{15}$ This political trend persisted in the country without adequate redress under the law despite the existence of anti-defection law in Nigeria.

It may not be wrong to describe the legal regimen calculated to remedy the situation in the country as a 'toothless bulldog' and without any working effect. The clinical manifestation of the above disposition came to light on the occasion of the open celebration by the main opposition, the PDP, accommodating the then incumbent Senate President Olusola Bukola Saraki ${ }^{16}$ of the ruling All Progressives Congress (APC) as well as the event that greeted the speaker of the lower chamber, Right Honourable Aminu Waziri Tambuwal ${ }^{17}$ from the then ruling PDP to the main opposition party APC in 2014 while retaining their respective seats in the parliament. The defection ${ }^{18}$ of the incumbent speaker of the Sokoto State House of Assembly Alhaji Salihu Maidaji and 17 other members of the Assembly along with Governor Aminu Waziri Tambuwal back to the PDP in $2018^{19}$ with impunity may also come to bear. Therefore, it need not be overemphasized that the Nigerian democracy is yet to have realistic and operational legal frameworks to sanitize the country's political realm.

Therefore, the extant provisions in the country on political defection cannot be seen to have discharged its purpose towards the attainment of social order to cement the society. It is not out of place to indicate that the dynamism of the law recounts to ensure social justice in all ramifications. Against this backdrop, this paper seeks to stem up working legal modalities to abreast the Nigerian democracy with the relevant and necessary legal tools to achieve its essence in this changing political era.

11 Sentell Barnes, "Defections, Decamping and Cross-Carpeting: The Challenges Facing Nigerian Political Parties Ahead of the 2019 General Elections," Democracy Speaks, 2018, https://www.democracyspeaks.org/blog/defections-decamping-and-cross-carpeting-challenges-facing-nigerianpolitical-parties-ahead.

12 A British Statesman, Orator and an Author. A two times Prime Minister of Great Britain Between 1940-1945 and 1951-1955

13 Simon Abah, "Political Defections in Nigeria, Causes and Consequences," The Guardian, 2018.

14 A Hollywood Movies Actor turned politician, the $33^{\text {rd }}$ Governor of California between $1967-1975$ and the $40^{\text {th }}$ President of the United States between 1981-1989.

15 Abah, "Political Defections in Nigeria, Causes and Consequences."

16 Egufe Yafugborhi, "Saraki, Ahmed Defection to PDP Another Reflection of APC Failure," Vanguard, 2018, https://www.vanguardngr.com.

17 Owede Agbajileke, "Tambuwal: A Defection So Controversial," Business Day, 2014, https://businessday.ng/exclusives/article/tambuwal-a-defection-so-controversial/.

18 This word will be used interchangeably

19 Onyebuchi Ezigbo, Mohammed Aminu, and Hammid Shittu, "Tambuwal, Abdullahi, 18 Sokoto Lawmakers Defect from APC to PDP," This Day, 2018, https://www.thisdaylive.com/index.php/2018/08/02/tambuwal-abdullahi-18sokoto-lawmakers-defect-from-apc-to-pdp/. 


\section{RESEARCH METHOD}

This work adopts the doctrinal method where both primary and secondary sources such as textbooks, articles in learned journals, papers, case laws, internet materials and so on would be relied upon. The doctrinal or conceptual legal research approach is the study of the law and all legal provisions the way they are in books in the form of statutes and case law, ${ }^{20}$ such as the Nigerian Constitution and the Nigerian Anti-Defection Law. Therefore, analysis of the implication of political defection on Nigeria's democracy will be better appreciated through the conceptual approach to appraising the legal impediments with effective control of political defection in Nigeria.

\section{ANALYSIS AND DISCUSSION}

\section{The Concept of Political Parties and Electoral Mandate Under Nigerian Law}

A political party is seen as an alliance of like-minded people who work together to win elections and control the government. ${ }^{21}$ It is also seen as an association of men and women who have similar views and organize themselves to obtain political power and control government machinery. ${ }^{22}$ Political Party, in another perspective, is seen as a group of persons who are organized in order to acquire and exercise political power. ${ }^{23}$ Hence, the precise and all-encompassing definition in the Constitution ${ }^{24}$ which is judicially endorsed in NCP v National Assembly, FRN. ${ }^{25}$ which state that "Any association whose activities including canvassing for votes in support of a candidate for election to the office of President, Vice-President, Governor, Deputy-Governor or Member of a Legislative House or a Local Government Council."

It follows that a political organization with a strong desire to attain and wield political power is a product of people of similar if not the same political philosophy and policies. It depicts that these like-minded people, though with different views and preferences, give into similar struggles and program with a zeal to achieving them on the attainment of power. Therefore, political parties are often espoused on expressed ideology or vision bolstered by a written platform with specific goals, forming a coalition among disparate interests, with a strong desire to protect the interest of its members upon victory, not to disappoint them by switching to another party of interest.

The term of defection concerning politics acquired different meanings and connotations as it is known in different nomenclature such as "Decamping", "Cross Carpeting", "Party Hopping", "Party Switching", "Party Crossover", and Canoe Jumping ${ }^{26}$ among others. It is defined as an act of swapping political parties or changing party allegiance, or moving from one party to another. ${ }^{27}$ Party Switching as described in the United Kingdom is a common occurrence where members of Labour,

\footnotetext{
${ }^{20}$ Alemika, E. I. "The National Approved Uniformed Formats and Citation Guides for Legal Research Writings in Law Faculties/Institutions in Nigeria" (2015)

21 Badejo B.T., Agunyai S.C., and S.O. Buraimo, "The Politics of Defection and Power Game in Nigeria: Insights from the 7th Lower Legislative Chamber," Public Policy and Administration Research 6, no. 9 (2016): 6-14.

22 Mbaya Paul, Element of Comparative Government and Administration (Maiduguri: Mike-B Printing Works, 2009).

23 Mustapha Alhaji Ali and Isah Shehu Mohammed, "Politics of Inter-Party Defections in Nigeria: Who's Interest?," African Journal of Management 3, no. 4 (2018): 127.

24 s. 229, Constitution of The Federal Republic of Nigeria, 1999

25 (2016) ${ }^{1}$ NWLR (Pt. 1492), 1 at 23.

26 BT, SC, and Buraimo, "The Politics of Defection and Power Game in Nigeria: Insights from the 7th Lower Legislative Chamber."

27 Lawrence I. Edet, "Politics of Defection and Its Implications on Nigeria's Democracy," Global Journal of HumanSocial Science: F Political Science 17, no. 1 (2017): 2.
} 
Conservative and Liberal Democrat hop when it suits them ${ }^{28}$ while the Nigerian model of 'Party Hopping' is a class on its own, in other words, 'Carpet Crossing' in the Nigerian context refers to a situation in which a member of Legislature (or Executive) elected on one party ticket changes his political allegiance before the next general election. ${ }^{29}$ Therefore, it follows from the preceding definition that political defection in all of its metamorphosis connotes a situation where an elected officeholder elopes along with the mandate of his electorate to another political platform irrespective of the differences in the mandate of the other groups for the purpose of conservation of office.

Electoral Mandate means an authority given to an elected group of people, such as the government, to perform an action or govern a country. ${ }^{30}$ It also refers to the authority to carry out a policy regarded as given by the electorates to a party or candidate that wins an election. ${ }^{31}$ It means that mandated policies are typically perceived to be those contained in the party's manifesto at the relevant election before taking power. ${ }^{32}$ These definitions can be instructive towards understanding the level of indebtedness of political office holders to their electorates after winning the election. It suffices to say that by the mere casting of votes in favour of a candidate, the voters have by so doing entrusted the winning candidate with their harmonized political policies and programmes as contained in their party's manifesto. It is to give effect to the mandate, which is the command or authorization to act in a particular way on a public issue given by the electorates to its representative ${ }^{33}$ at the time of election. It has never been the case anywhere in Nigeria that part of the nature and conditions of the mandate given to any candidate at the point of election by the electorates is to defect or 'Cross the Carpet' when it becomes unbearable. Hence, the electoral mandate becomes real at the moment of the election with no time to amend or vary before the expiration of the mandated term. Thus, Thomas Mazur posited that. "It is fairly cut and dried once a vote has been taken. An issue is presented and then voted on by the body, and it either passes or fails according to vote". ${ }^{34}$

It goes without saying that the moment a political office holder defects, the expectation of the voters which informed their decision to belong together in a particular political platform becomes defeated. This is because the harmonized political policies, vision, values and programmes may not be the same as that of the favoured party, thereby breaking faith with the electorates.

\section{Brief History of Political Defection}

The antecedence of 'Party-Hopping' in Nigeria is not unconnected with the then status of the country as a colony of the British government. It was the practice in the British Parliament to have its members separated by a red carpet according to the opinion held on a prevalent issue to be decided. ${ }^{35}$ Any member from either side of the divide can decline his initial opinion and cast his vote in favour of the other side by crossing the red carpet to join the other side and vice versa till a decision

28 M. E. Blunt, “Carpet-Crossing,” Parliamentary Affairs 18, no. 1 (1964): 82-91, https://academic.oup.com/pa/articleabstract/XVIII/1/82/1518268?redirectedFrom=fulltext.

29 Blunt.

30 www.dictionarycambrige.org, accessed on 19 July 2020.

31 www.tutor2u.net/politics/topic, accessed on 19 July 2020.

32 BT, SC, and Buraimo, "The Politics of Defection and Power Game in Nigeria: Insights from the 7th Lower Legislative Chamber."

33 www.dictionary.com, accessed on 19 July 2020.

34 T. J Mazur, "When Is an Electoral Mandate Really A Mandate?," erie.gov, 2007, www.erie.gov/legislature/ district08district08news021207asp.

35 O. Alaba, "A Season of Carpet Crossing," Niger Delta Congress, 2007, www.nigerdeltacongress.com/ articles/aseasonofcarpetcrossing.htm. 
is reached. ${ }^{36}$ The Nigerian political imbroglio widened the innovation to include an act of leaving one's party to another.

The landmark incident of "Ship-Jumping" in Nigeria was recorded in 1957 when members of the NCNC were lobbied to cross over to the Action Group (AG) ${ }^{37}$ on the floor of the Western Nigerian House of Assembly. It resulted in a significant deflation in the political strength of the party in the house and a good ground that compelled Nnamdi Azikiwe to shift base to the Eastern Region where his party had dominated. ${ }^{38}$ There were series of rivalry and personality issues that greeted this development up to the post-independent era. Notably, this resulted in the mistrust between the regions that was relevant to not only the two illustrious nationalities to wit Awolowo and Azikiwe, but also to their respective kinsmen. ${ }^{39}$

This nascent political development matured through transitional politics with an endless list of events to become more adorable and almost a political norm in the most controversial fourth republic. The celebrated case in this republic include those of Alhaji Atiku Abubakar, who decamped from the ruling PDP to Action Congress in $2006^{40}$ with the chain of unsuccessful legal battles with the PDP led government of Chief Olusegun Matthew Aremu Obasanjo. ${ }^{41}$ The case of the erstwhile speaker of the lower chamber Right Honourable Aminu Waziri Tambuwal where he jumped from the ruling party PDP to the opposition All Progressives Congress in $2014^{42}$ and that of the erstwhile President of the Upper Chamber, Olusola Bukola Saraki, who crossed from the ruling APC back to the main opposition, the PDP, in 2018. ${ }^{43}$ The most recent defections of the sitting governor of Ebonyi State, ${ }^{44}$ Governor David Umahi and that of the serving member of the $9^{\text {th }}$ Assembly, Senator Elisha Ishaku Abbo (representing Adamawa North Senatorial District) ${ }^{45}$ both from the main opposition party PDP to the ruling APC with impunity are both instances that do not seem to end the gale of defection in the country.

It is discernible that the trend of cross carpeting in Nigerian politics is yet to be kept under effective control. Therefore, the tendency of the menace of Party-Switching among Nigerian politicians to blossom soon is ostensibly certain.

\section{Causes for Decamping \\ Lack of Ideology}

In the Nigerian context, political parties were formed only to satisfy the constitutional ${ }^{46}$ requirement $^{2}$ of membership and sponsorship ${ }^{47}$ for elections, but utterly bereft of political ideologies. A careful

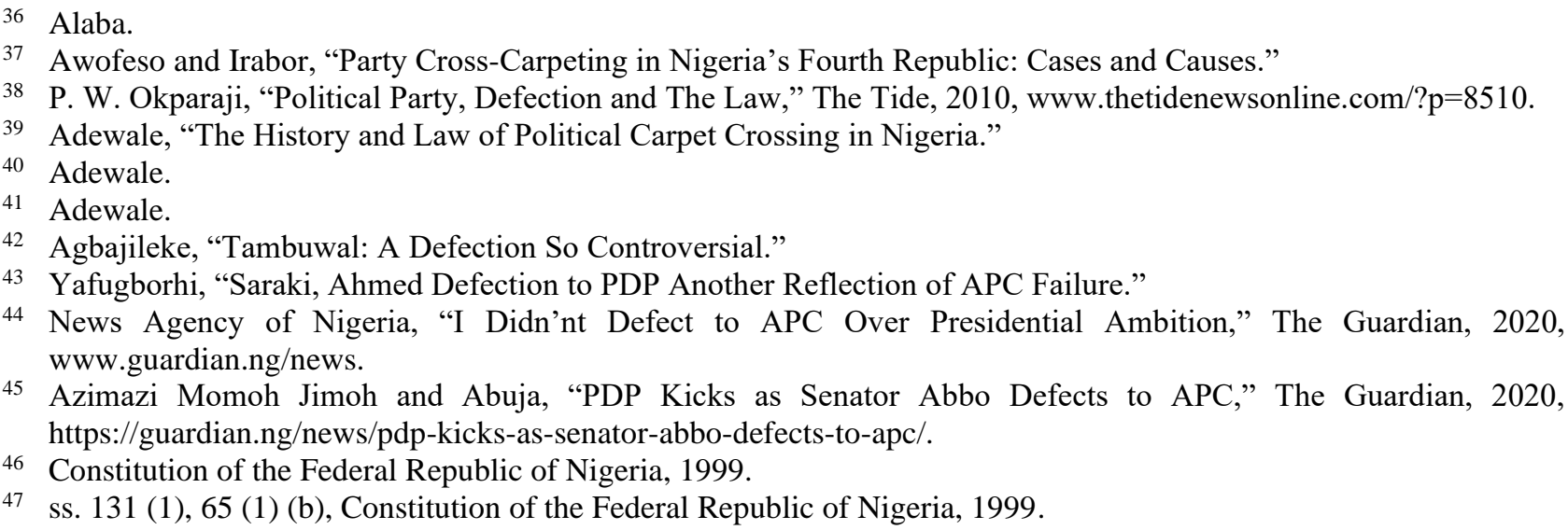


study of Nigerian politics would reveal that "political parties in Nigeria are composed of persons with different ideologies who do not only misunderstand themselves but are regularly feuding". ${ }^{8}$

This finding, among others, have accounted for the party's ideological scantiness and the prevailing cases of Party-Hopping ${ }^{49}$ in Nigeria. This is in contrast with the case in Advance Democracies; USA, Britain, Germany ${ }^{50}$ and so on where parties were based on entrenched ideologies and not seen merely as means to attain political power.

\section{Lack of internal democracy}

Most political parties in Nigeria were formed, sponsored and managed by a few political big wigs. These powerful managers of the party remained the final think tanks of these parties, so much so that their stance regarding any issue on the party's affairs becomes sacrosanct, come what may. In the event of displeasures occasioned by their decisions, an aggrieved member may find solace under another political platform to retain power. It is observed that "intraparty crisis in Nigeria underlies the burgeoning states of party defection in Nigeria...these crises have the corresponding impact on the political system and sometimes ensue in members defecting to other parties". ${ }^{51}$

The same circumstances explained the political quagmire that saw the influx of some politicians to the then major opposition party, the APC, in 2014 to remain within the corridors of power. It was aptly stated that:

"Intraparty crisis within the PDP is also one reason that has made lawmakers at the lower legislative chambers defect to other parties... It is a conflict by party men and women to outwit one another in the control of party (sic) machinery ahead of the 2015 general election. It is important to note that the defection of some PDP lawmakers to APC was borne of out numerous crises ravaging the party ranging from (Sic) choice of Babanga (Sic) Tukur as the National Chairman to the suspension of Amaechi Rotimi, and the Governor of Sokoto for acting against the party (Sic) decision not to run as NGF chairman and to vote against the party (Sic) choice respectively and also the crisis of who becomes the party national Secretary among others."

The above scenario appears replicated in the case of Senator Abbo's defection when he stated that "his decampment was made inevitable by Governor Ahmadu Umaru Fintiri's alleged polarization of the PDP in the North East (sic) State". ${ }^{53}$ It follows from the preceding that the primacy of political power constantly determined membership to political parties at the detriment of the voters. It had simply lent credence to the fact that political power directly results in economic power and connects to the location and distribution of economic resources and political rewards. ${ }^{54}$

\section{Lack of national interest}

National Interest is the interest of a nation as a whole held to be an independent entity separate from the interest of subordinate areas or groups and also of other nations or supranational groups ${ }^{55}$ In contrast, national interest in the Nigerian context can be seen in the Marxist approach to mean the

\footnotetext{
Awofeso and Irabor, "Party Cross-Carpeting in Nigeria’s Fourth Republic: Cases and Causes."

Awofeso and Irabor.

Edet, "Politics of Defection and Its Implications on Nigeria's Democracy."

51 Jaja Nwanegbo, Jude Odigbo, and Kingsley Nnorom, "Party Defection and Sustenance of Nigerian Democracy," Global Journal of Human-Social Science: F Political Science 14, no. 6 (2014): 3.

52 BT, SC, and Buraimo, "The Politics of Defection and Power Game in Nigeria: Insights from the 7th Lower Legislative Chamber."

53 Jimoh and Abuja, "PDP Kicks as Senator Abbo Defects to APC."

54 Awofeso and Irabor, "Party Cross-Carpeting in Nigeria's Fourth Republic: Cases and Causes."

55 H. J. Morgenthau, "Definition of National Interest," Merriam-Webster, 2020.
} 
ruling class's interest. ${ }^{56}$ In other words, defecting political office holders in Nigeria may hold onto the nation's interest in justification for their acts of defection. Hence, the paradoxical statement accredited to Chief Olusola $\mathrm{Oke}^{57}$ on the occasion of his defection from PDP to APC in 2015. When he said he could not resist the wind of change that was blowing across the country, which must pass through Ondo State ${ }^{58}$ owing to his defection. However, on a seeming comical reflection of the net purpose of his defection, which is devoid of interest of the nation, he confessed regretting defection because he suffered humiliation. ${ }^{59}$ in the ruling APC.

Similarly, tribal egoism has constituted another threat to the Nigerian democracy, which serves as opium capable of standing in place of national interest, as depicted by the index case of defection in Nigeria. In which case, all Yoruba members of the NCNC in the defunct Western Region House of Assembly were easily lobbied to dump their original party in favour of the Yoruba dominated party, the AG, in order to achieve their goal of denying the non-Yoruba leader of their party, Nnamdi Azikiwe the chance of becoming the Premier of Western Region. ${ }^{60}$

The most recent political imbroglio brewed in the defection of the erstwhile speaker of the lower chamber and now a member of the green chamber, Right Honourable Yakubu Dogara, back to the ruling party, APC may become classical. The defection of the former speaker has since been plastered in the national interest. ${ }^{61}$ However, the remote desire responsible for his defection was technically revealed in the latter part of the statement, which says, "Dogara's defection portends a good omen for APC's readiness for 2023". ${ }^{62}$ It can be inferred that President Buhari's succession plan ${ }^{63}$ might be the spotlight of the federal lawmaker's decision to rejoin the ruling APC against the acclaimed national interest. It is discernible from the long history of political defection in the country that the nation's interest has never formed the basis for defection in any case rather than the permanent interests of the politicians. ${ }^{64}$

\section{Effects of Political Defection in Nigeria}

The spate of political defection in the country is not without some indelible prints on Nigeria's fledgling democracy. This political dissonance in whatever guise possible is fast attaining normative status in the country's political culture. The mammoth cloud of defection that covers all political parties across the country usually carves these effects on the structure of the country's democracy.

The archive of defection in Nigeria is glaringly overwhelmed with the records of defection into a ruling party. ${ }^{65}$ Consequently, the strength of the opposition parties would spontaneously be

56 Dahiru Hussaini Attah, "Foreign Policy Decisions and National Interests: Reflecting on the Experience of the Greentree Agreement," Jalingo Economic and Business Review 3, no. 3 (2019): 148.

57 The former National Legal Adviser of the PDP and a one time candidate for the 2012 gubernatorial election in Ondo state.

58 Awofeso and Irabor, "Party Cross-Carpeting in Nigeria's Fourth Republic: Cases and Causes."

59 Dayo Johnson, "I Regret Returning to APC," The Vanguard, 2018, https://www.vanguardngr.com.

60 Awofeso and Irabor, "Party Cross-Carpeting in Nigeria's Fourth Republic: Cases and Causes."

61 Leo Sobechi, “Dogara's Defection Exposes APC, PDP's 2023 Schemes,” The Guardian, 2020, https:/guardian.ng/ politics/dogaras-defection-exposes-apc-pdps-2023-schemes/.

62 Sobechi.

63 Sobechi.

64 Proshare Webtv, "7 Reasons Why Politicians Defect in Nigeria," Proshare, 2018, https://www. proshareng.com/news/Politics/7-Reasons-Why-Politicians-Defect-in-Nigeria/41052.

65 Awofeso and Irabor, "Party Cross-Carpeting in Nigeria's Fourth Republic: Cases and Causes." 
drained in staging a much desired competitive democracy. ${ }^{66}$ This becomes manifest in the inevitable loss of the spirits of opposition ${ }^{67}$ suffered by the abandoned parties. The ruling party ended up with a monopoly of politics and governance devoid of reasonable criticisms.

Moreover, the staggering posture of the defecting politicians further compounded the polity in vertigo that usually bewildered the electorates in the political realm. The voters hardly decide which political bloc to align themselves as the parties now differ only in names against the politics of likemindedness, which compelled the impression that political parties "operating in Nigeria are nothing but an organization managed by opportunists". ${ }^{68}$ It also results in the anguish palpably vented out by some aggrieved electorates. A voter lamented when condemning the defection of some party members that "The decision he (Honourable Satty Gogwim) took and the reason he gave for changing his political party, in my opinion actually portrayed him as an unprincipled politician. That is a politician that lacks focus, a politician without vision, a politician without a programme." ${ }^{69}$ Similarly, another round of display by an electorate aptly summarized the predicament in the following words. "Cross Carpeting is a sign of cowardice. It is also a sign of insincerity and the absence of principle." ${ }^{70}$ From the preceding, one can safely come to terms with the notorious fact that if defecting to another political platform continues to enjoy impunity, then the polity may not augur well with the attending repercussions.

\section{The Nigerian Anti-Defection Law}

The relevant Nigerian law on defection is yet to accommodate enough provisions for the effective control of the menace in the country. This is practically demonstrated in the absence of any punitive measures to checkmate political 'prostitution' in the executive arm of government. Despite the vital role of this arm of government in realizing the set goals of a party through policy making and execution, the law facilitated the practice of carpet crossing in the executive, which resulted in judicial matrimony with the robbery of the people's mandate. Thus, in Abubakar v AG Federation ${ }^{71}$ the apex court declared constitutional the act of cross carpeting when it held that:

"It was not the intention of the makers of the Constitution of the Federal Republic of Nigeria, 1999 that if the President or Vice President resigns from the Political Party on whose platform he was elected into and embraced a rival Political Party his office becomes vacant because if that was the intention of the makers of the Constitution, they would have so stated expressly."72

Similarly, the court further anchored the act of defection by the elected executive officeholders to exercise a constitutional right. ${ }^{73}$ This position of the court has been followed in the case of the former Governor of Zamfara State Alhaji Mahmud Aliyu Shinkafi and his deputy Alhai Mukhtari Ahmed Anka. ${ }^{74}$

\footnotetext{
Nwanegbo, Odigbo, and Nnorom, "Party Defection and Sustenance of Nigerian Democracy."

Awofeso and Irabor, "Party Cross-Carpeting in Nigeria's Fourth Republic: Cases and Causes."

8 Edet, "Politics of Defection and Its Implications on Nigeria's Democracy."

69 I. Abdulsalami, "Defection of ANPP Member Raises Dust in Jos," The Guardian, 2010.

70 Y. A. Nasidi, "Party Cross-Carpeting Is a Sign of Cowardice," Allafrica, 2009, www.allafrica.com/ stories/200911230312.html.

71 (2007) 3 NWLR (Pt.1022). p.618

72 Abubakar v AG Federation, (Supra)

73 S. Tobi, “Atiku Remains Vice President,” Punch Newspaper, 2007.

74 Tobi.
} 
It follows from the above; the freedom of members of the executive arm to "cross-over" with impunity may render the hope of the electorates awaiting the realization of their political manifestoes through policymaking dependent on the similarity or otherwise of that of the favoured party. More so, the hope of these electorates may become shattered if it were in an Advanced Democratic setting or even when a political association in Nigeria is based on entrenched ideologies.

In contrast, the same cannot be said of the elected legislators across the country whose freedom of Assembly and association ${ }^{75}$ is hinged on the provision of sections 68 (1) (g) and 109 (1) (g), both of the Constitution. ${ }^{76}$ These twin sections in pari-materia provide to the effect that a member of either the Federal or State Legislature shall vacate his seat when he changes his Political Party under which platform he was elected and before the expiration of his term of office. These sections were interpreted by the courts in Nigeria to curb the excesses perpetrated through the rampant practice of "Cross Carpeting""77 by elected legislators. Thus, the court in Honourable Michael Dapianlong and Others $v$ Chief (Dr.) Joshua Chibi Dariye ${ }^{78}$ per Katsina Alu JSC (as he then was) declared vacant the seat of 14 members of the Plateau State House of Assembly out of 24 members, including the speakers and his deputy who defected from the PDP to APC in 2010. In concurring to the declaration, Mahmud Muhammad JSC" (as he then was) held that "It is not in dispute that 14 of the 24 members of the House has (sic) vacated their seat under section 109 (1) (g) of the same Constitution." 80

Interestingly, the law may seem to be brutal enough in effecting a wholesome approach on the menace of "Cross Carpeting" in the Legislative Houses. However, a painstaking study of the law may impart otherwise. The scepticism of the drafters of the Constitution is apparent in the proviso to the twin sections, which introduced division in or merger of the parties to cushion the effect of the main provision. However, the paucity of the law on the nature and degree of the division or factions in a party to qualify the justification offered in the proviso to the law constituted an effective escape route to defecting elected members. This has practically been the case with our decamping legislators, who habitually hinged on the flimsiest ground that could even be rehearsed with a willing partner to cross over. The implication is that no member in the recent past ever vacated his seat, even with the unfounded excuses bereft of substance ${ }^{81}$ offered by the defectors. Thus, the lamentation of the immediate past Senate President Bukola Olusola Saraki when defecting back to PDP as part of his reason stated that "I will like to emphasize that it is a decision that has been inescapably imposed on me by certain elements and forces within the APC; All government principles which were required for a healthy functioning of the party and the government were deliberately violated or undermined." 82

A similar statement was vaguely made by the former speaker of the House of Representatives Right Honourable Aminu Waziri Tambuwal when he nailed his reason for crossing to the APC in

\footnotetext{
s. 40 of the Constitution of the Federal Republic of Nigeria, 1999

Constitution of the Federal Republic of Nigeria, 1999

Agbegunde v O.S.H.A. $(2015)^{8}$ NWLR (Pt. 1461), 314

(No.2), (2007) ${ }^{8}$ NWLR (Pt. 1036), 332

Former Chief Justice of Nigeria

Hon. Michael Dapianlong v Dariye (Supra)

1 Olaolu Stephen Apadere and Julius O. Agbana, "Cross Carpeting in Nigerian Politics: Some Legal and Moral Issues Generated," Frontiers of Legal Research 3, no. 2 (2015): 33.

82 Channels Television, "Why I Defected From APC To PDP," Channels, 2018, https://www.channelstv. com/2018/07/31/why-i-defected-from-apc-to-pdp-saraki.
} 
2014 on the provision of this law. Thus "In pursuit of the provisions of the 1999 Constitution and given the political developments in my state, I wish to inform you of my membership of the APC" formally. ${ }^{83}$ This pregnant statement of the defunct speaker of the Lower Chambers is a vivid account of how our defecting legislatures dribble the Nigerian Anti Defection Law. The cacophony of voices of Nigerian electorates may not cease anytime near when the only legal remedy available is treated with levity owing to its porosity.

The inefficiency of the law is further broadened when it vests the power to declare vacant the seat of any defecting member on the Principal Officers ${ }^{84}$ of the respective chambers. These officers might ceremoniously proclaim the law on any defecting member, especially when leaving the officer's party. However, it is foolhardy to expect our cunning politicians to do the same on themselves. In other words, the principal officers, as were the case with Saraki, Tambuwal and Maidaji would not be expected to declare their personal seats vacant when they defected. More so, they would clearly decline to operate the law on any ordinary member who either crosses along with them or into their political party. In the long run, the law must be seen to be deficient in as much as it fails to achieve the desired social control as an element of coercion. ${ }^{85}$

The wording of the twin provisions is another conundrum that added to the turmoil around the recurrent cases of Cross Carpeting in Nigeria. The phrase "shall vacate his seat" as contained in the sections does not only call for legal tussles towards the construction of the word "shall" which has variously been held as capable of bearing many meanings ${ }^{86}$ as either directory ${ }^{87}$ or obligatory $^{88}$ but also favours serial litigation on each and every case of defection for the operation of the law. Unlike the provision in Nigeria, the law in India provides that "A member of a House belonging to any political party shall be disqualified for being a member of the house if he has voluntarily given up his membership of such political party". 89

The Indian Supreme Court has interpreted the above provision in Ravi S. Naik v Union of In$d i a^{90}$ giving effect to the phrase "Voluntarily given up his membership of such Political Party" to include formal resignation by the defecting member. This entails that a legislator is required to formally tender his/her resignation in default of which the presiding officer will invoke his power ${ }^{91}$ to excommunicate the erring member. Therefore, the laid down procedure is that a defector will honourably resign, and the presiding officer will consider the resignation letter and detach him as a member if satisfied with the content or decline, which decision may be challenged in court. ${ }^{92}$

Although the two countries appear to have identical provisions against political defection, the Indian law seems to offer a broader connotation and a more effective, more accessible and faster application in juxtaposition to the litigious provision in Nigeria. The inadequacy of the Nigerian law

83 Daily Newa Headlines, "Finally, Tambuwal Defects to APC," PM News, 2014, https://pmnewsnigeria. com/2014/10/28/finally-tambuwal-defects-to-apc.

84 ss.68 (2) and 109 (2) of the Constitution of the Federal Republic of Nigeria, 1999.

85 A. O. Sanni, Introduction to Nigerian Legal Method (Ile-Ife: Kuntel Publishing House, 1999).

86 Vibelko (Nig.) Ltd v N.D.I.C. (2006) ${ }^{12}$ NWLR (Pt. 994), p.280.

87 A. T. Ltd v ADH (2007) $)^{15}$ NWLR (Pt. 1056), p.118.

88 Olowokere v African Newspaper (1993) ${ }^{5}$ NWLR (Pt. 295), p.583.

89 Tenth Schedule of the Constitution of India, 1949.

90 (1994) AIR 1558.

91 Art. 190 (3). The Indian Constitution, 1949.

92 Kihoto Hollohan v Zachillin and Ors. 1992 SCR (1) 686. 
on defection is no less than what Malhotra" aptly described. Thus, "The various issues of political defection (In Nigeria) ${ }^{94}$ are yet to be fully addressed and politically and legally tested. ${ }^{95}$ Consequently, it will not be out of place to conclude that the rudimentary position of the law on defection substantially accounts for the recurring cases of "floor crossing", which also stagnates the consolidation of democracy in Nigeria.

\section{CONCLUSION}

As a weaning child of Great Britain, Nigeria received, among other things, the British Parliament's system of "crossing the red carpet" to cast a vote in support of ideas to reach a decision. In the Nigerian parlance, it connotes switching political alliances not only by the member of the parliament but also elected executives. This invariably explains the impunity enjoyed by the defecting elected executives, which paucity mandated the courts to not only legalize the political harlotry but embellished it as an exercise of a right to assemble and associate without penalty freely. Although the court was quick to excoriate the practice as questionable and morally reprehensible, ${ }^{96}$ until it possesses the force of law, the immoral practice of defection will continue to enjoy a high degree of

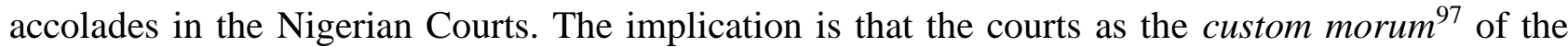
people will be made to acquaint with the consequences of divorcing law from morality ${ }^{98}$ on the country's fledgling democracy. Hence, the call for a new clause to be implanted after paragraph (c) of sections 135 and $180^{99}$ of the Constitution to decisively address defection by the executives ${ }^{100}$ becomes sacrosanct.

The porosity of the existing law on defection in Nigeria ought to have been think of the past in cognizance of the index case of defection in Nigeria. However, it is logical to understand that reformation of the law might be tantamount to 'shooting oneself on foot' when the extant law with its attending porosity favours the same body responsible for the task. So long as the democratic system remains the government of the masses, the voices of the masses for law reforms shall ceaselessly make a difference. Therefore, a robust reform of the laws will go a long way in making the necessary changes towards protecting the interests of the traumatized electorates, thereby strengthening the threatened democracy. The Constitution should be amended to couch its provisions in a way that would mandate a defecting legislator and within the shortest time frame to tender his resignation after decamping to another Political Party honourably. This will be feasible, primarily when the amendment covers the degree of division and kind of merger that can call for defection from any interested member. The power conferred on the presiding officers of legislative chambers as envisaged in Sections 68 (2) and 109 (2) of the Constitution be amended to provide for the time frame within which a verdict on the resignation, if any, tendered by a defecting legislator must be delivered upholding resignation of the member or otherwise. It should also be couched to empower the

93 G. C. Malhotra, Anti-Defection Law in India and the Commonwealth (New Delhi: Lok Sabha Secretariat, 2005).

94 Emphasis added

95 Malhotra, Anti-Defection Law in India and the Commonwealth.

96 S. Aliyu, "Court Dismisses Suit Against Shinkafi,” Daily Trust Newspaper, 2009.

97 Keepers of Morals

98 R v Dudley and Stevens (1889) ${ }^{14}$ QBD, 287

99 E. Aziken, "Cross Carpeting: A Threat to Our Democracy," Allafrica, 2009, www.allafrica.com/ stories/200907061229.html.

100 President and the Vice-President, as well as States' Governors and their Deputies, 
head of legislative chambers further to proceed and determine the resignation of the defecting member with or without the resignation notice but after the expiration of the allotted time frame. The Constitution should be amended to provide for the power to declare vacant the seat of the Presiding Officers of the legislative chambers on the Executive President and the Governor of a state in the event of defection by these officers. Alternatively, a Constitutional Court is established, or a constitutional bench is introduced in the Federal High Court with investigative and prosecutorial power on its Chief Registrar to enforce among other Constitutional issues all or any of the above suggestions expeditiously.

\section{REFERENCES}

Abah, Simon. "Political Defections in Nigeria, Causes and Consequences." The Guardian, 2018.

Abdulsalami, I. "Defection of ANPP Member Raises Dust in Jos." The Guardian, 2010.

Adewale, A. "The History and Law of Political Carpet Crossing in Nigeria." Squib Guest, 2009. www.squibguest.blogspot.com.

Agbajileke, Owede. "Tambuwal: A Defection So Controversial." Business Day, 2014. https://businessday.ng/exclusives/article/tambuwal-a-defection-so-controversial/.

Akpambang, Enobong Mbang, and Omolade Adeyemi Oniyinde. "Political Party Defections by Elected Officers in Nigeria: Nuisance or Catalyst for Democratic Reforms?" International Journal of Research in Humanities and Social Studies 7, no. 2 (2020): 12.

Alaba, O. "A Season of Carpet Crossing." Niger Delta Congress, 2007. www.nigerdeltacongress.com/articles/aseasonofcarpetcrossing.htm.

Alemika, E. I. "The National Approved Uniformed Formats and Citation Guides for Legal Research Writings in Law Faculties/Institutions in Nigeria" (2015)

Ali, Mustapha Alhaji, and Isah Shehu Mohammed. "Politics of Inter-Party Defections in Nigeria: Who's Interest?” African Journal of Management 3, no. 4 (2018): 127.

Aliyu, S. “Court Dismisses Suit Against Shinkafi.” Daily Trust Newspaper, 2009.

Apadere, Olaolu Stephen, and Julius O. Agbana. "Cross Carpeting in Nigerian Politics: Some Legal and Moral Issues Generated.” Frontiers of Legal Research 3, no. 2 (2015): 33.

Attah, Dahiru Hussaini. "Foreign Policy Decisions and National Interests: Reflecting on the Experience of the Greentree Agreement." Jalingo Economic and Business Review 3, no. 3 (2019): 148.

Awofeso, Olu, and Paul A. Irabor. "Party Cross-Carpeting in Nigeria's Fourth Republic: Cases and Causes." Journal of Public Administration and Governance 6, no. 9 (2016): 34.

Aziken, E. "Cross Carpeting: A Threat to Our Democracy." Allafrica, 2009. www.allafrica.com/stories/200907061229.html.

B.T., Badejo, Agunyai S.C., and S.O. Buraimo. "The Politics of Defection and Power Game in Nigeria: Insights from the 7th Lower Legislative Chamber." Public Policy and Administration Research 6, no. 9 (2016): 6-14.

Barnes, Sentell. "Defections, Decamping and Cross-Carpeting: The Challenges Facing Nigerian Political Parties Ahead of the 2019 General Elections." Democracy Speaks, 2018. https://www.democracyspeaks.org/blog/defections-decamping-and-cross-carpeting-challengesfacing-nigerian-political-parties-ahead. 
Blunt, M. E. "Carpet-Crossing." Parliamentary Affairs 18, no. 1 (1964): 82-91. https://academic.oup.com/pa/article-abstract/XVIII/1/82/1518268?redirectedFrom=fulltext.

Constitution of the Federal Republic of Nigeria, 1999

Edet, Lawrence I. "Politics of Defection and Its Implications on Nigeria's Democracy." Global Journal of Human-Social Science: F Political Science 17, no. 1 (2017): 2.

Ezigbo, Onyebuchi, Mohammed Aminu, and Hammid Shittu. "Tambuwal, Abdullahi, 18 Sokoto Lawmakers Defect from APC to PDP." This Day, 2018. https://www.thisdaylive.com/index.php/2018/08/02/tambuwal-abdullahi-18-sokotolawmakers-defect-from-apc-to-pdp/.

Headlines, Daily Newa. "Finally, Tambuwal Defects to APC." PM News, 2014. https://pmnewsnigeria.com/2014/10/28/finally-tambuwal-defects-to-apc.

Jimoh, Azimazi Momoh, and Abuja. "PDP Kicks as Senator Abbo Defects to APC." The Guardian, 2020. https://guardian.ng/news/pdp-kicks-as-senator-abbo-defects-to-apc/.

Johnson, Dayo. "I Regret Returning to APC.” The Vanguard, 2018. https://www.vanguardngr.com.

Malhotra, G. C. Anti-Defection Law in India and the Commonwealth. New Delhi: Lok Sabha Secretariat, 2005.

Mazur, T. J. "When Is an Electoral Mandate Really A Mandate?" erie.gov, 2007. www.erie.gov/legislature/district08district08news021207asp.

Morgenthau, H. J. "Definition of National Interest.” Merriam-Webster, 2020.

Nasidi, Y. A. "Party Cross-Carpeting Is a Sign of Cowardice." Allafrica, 2009. www.allafrica.com/stories/200911230312.html.

Nigeria, News Agency of. "I Didn'nt Defect to APC Over Presidential Ambition." The Guardian, 2020. www.guardian.ng/news.

Nwanegbo, Jaja, Jude Odigbo, and Kingsley Nnorom. "Party Defection and Sustenance of Nigerian Democracy." Global Journal of Human-Social Science: F Political Science 14, no. 6 (2014): 3.

Okparaji, P. W. "Political Party, Defection and The Law." The Tide, 2010. www.thetidenewsonline.com/?p=8510.

Paul, Mbaya. Element of Comparative Government and Administration. Maiduguri: Mike-B Printing Works, 2009.

Sanni, A. O. Introduction to Nigerian Legal Method. Ile-Ife: Kuntel Publishing House, 1999.

Sobechi, Leo. "Dogara's Defection Exposes APC, PDP's 2023 Schemes.” The Guardian, 2020. https://guardian.ng/politics/dogaras-defection-exposes-apc-pdps-2023-schemes/.

Television, Channels. "Why I Defected From APC To PDP." Channels, 2018. https://www.channelstv.com/2018/07/31/why-i-defected-from-apc-to-pdp-saraki.

Class Hall. "The Great Nigeria Peoples Party (GNPP)," 2021.

Tobi, S. “Atiku Remains Vice President.” Punch Newspaper, 2007.

VOA. "Nigeria's Opposition Party Chooses Vice President Atiku Abubakar as Presidential Candidate." voanews.com, 2009. https://www.voanews.com/archive/nigerias-opposition-partychooses-vice-president-atiku-abubakar-presidential-candidate. 
Webtv, Proshare. "7 Reasons Why Politicians Defect in Nigeria." Proshare, 2018. https://www.proshareng.com/news/Politics/7-Reasons-Why-Politicians-Defect-inNigeria/41052.

Yafugborhi, Egufe. "Saraki, Ahmed Defection to PDP Another Reflection of APC Failure." Vanguard, 2018. https://www.vanguardngr.com. 